\title{
Pengaruh Dosis Aluminium Sulfat Terhadap Kekeruhan dan Kadar Besi Air Baku pada IPA PDAM X
}

\author{
Dimas Frananta Simatupang ${ }^{\text {, Gimelliya Saragih }}{ }^{\text {, }}$, Martin Siahaan ${ }^{1}$ \\ ${ }^{I}$ Politeknik Teknologi Kimia Industri, Jl. Medan Tenggara VII, Medan, 20228, Indonesia
}

\section{ARTICLE INFORMATION}

Received: April 29, 2021

Revised: June 01, 2021

Available online: June 28, 2021

\section{KEYWORDS}

Aluminum Sulfate, Iron Content, Raw Water, Turbidity

\section{CORRESPONDENCE}

Name: Dimas Frananta Simatupang

E-mail: difratas@ptki.ac.id

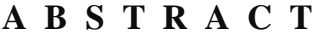

One of the first steps in processing river water into drinking water is by removing the turbidity of the river water. Turbidity can be removed by adding a chemical called a coagulant. This study aims to obtain data on how the effect of using coagulant dosage variations in reducing turbidity and iron content in raw water at the water treatment plant (IPA) PDAM X. The study was conducted using the jar test method to determine the dose of aluminum sulfate coagulant in reducing turbidity and colorimetric method using visible spectrophotometry to determine iron content that meets quality standard criteria. The results showed that the higher the coagulant dose, the lower the turbidity and iron content of the raw water. Coagulant doses with up to 30 ppm were able to reduce turbidity with an efficiency of $92.67 \%$ and reduce iron levels up $96.10 \%$.

\section{PENDAHULUAN}

Peningkatan kuantitas air merupakan syarat kedua setelah kualitas, karena semakin maju tingkat hidup seseorang maka akan semakin tinggi pula tingkat kebutuhan air di masyarakat tersebut. Selain itu pula air yang kita pergunakan setiap hari tidak lepas dari pengaruh pencemaran yang diakibatkan oleh ulah manusia juga beberapa bahan pencemaran seperti bahan mikrobiologi (bakteri, virus, parasit) bahan organik (pestisida, deterjen) dan beberapa bahan anorganik (garam, asam, logam), serta beberapa bahan kimia lainnya sudah banyak ditemukan dalam air yang kita pergunakan [1]. Air bersih yang layak digunakan harus memenuhi beberapa pengujian yang meliputi parameter fisik dan kimia berdasarkan Peraturan Menteri Kesehatan RI No. 32 tahun 2017. Parameter fisik meliputi tidak berbau, tidak keruh, tidak berwarna, tidak berasa, suhu normal, tidak mengandung zat padatan dan $\mathrm{pH} 7$. Sementara parameter kimia meliputi nilai dissolved oxygen (DO), biological oxygen deman (BOD) dan chemical oxygen demand (COD) dalam batasan normal, tidak sadah dan tidak mengandung senyawa kimia yang beracun [2].
Instalasi Pengolahan Air (IPA) PDAM X merupakan salah satu IPA yang berada di Provinsi Sumatera Utara yang mengolah air baku yaitu air sungai menjadi air yang bersih dan didistribusikan ke masyarakat setempat. Pengolahan air bersih ini melalui beberapa tahap pada unit-unit pengolahan meliputi tahap filtrasi pada Raw Water Tank (RWT), tahap koagulasi dengan larutan Aluminium Sulfat pada Splitter Box, tahap penjernihan air pada clearator kemudian dilakukan tahap filtrasi kembali pada filter section, dialirkan ke reservoir untuk tahap netralisasi $\mathrm{pH}$ air bersih dan air bersih didistribusikan dengan finished water pump.

Dalam proses menghilangkan kekeruhan pada air baku umumnya digunakan suatu koagulan yang memiliki fungsi untuk membentuk partikel kotoran yang terkandung dalam air menjadi gumpalan yang berukuran lebih besar sehingga lebih cepat mengendap. Pada proses ini biasanya sebagian besar kadar logam berat seperti besi (Fe) yang terkandung pada air baku juga ikut berkurang [3]. Koagulan yang digunakan bermacam-macam sesuai dengan kondisi air baku (air sungai) karena biasanya keunggulan bersifat menurunkan $p H$ (Power of Hidrogen) dalam air. Beberapa jenis koagulan yang 
dapat dipakai dalam pengolahan air dan dapat menurunkan kadar logam berat dalam air diantaranya adalah PAC (Poly Alumunium Chloride), magnesium klorida dan tawas (Aluminium Sulfat). Ketiga koagulan tersebut dapat menurunkan kadar logam berat seperti timbal $(\mathrm{Pb})$, zinc $(\mathrm{Zn})$ dan besi $(\mathrm{Fe})$ dengan metode koagulasi-flokulasi [4] [5]. Selain itu ada beberapa metode lain yang umum digunakan untuk menurunkan kadar logam berat meliputi elektrokoagulasi, pengenceran dan adsorpsi [6] [8].

Penggunaan PAC sebagai koagulan sudah banyak dilakukan dalam wastewater treatment dan pengolahan air baku lainnya untuk menghilangkan kekeruhan dan mengeliminasi logam berat besi pada sampel air baku ataupun air limbah. Penggunaan koagulan lainnya seperti aluminium sulfat telah dilakukan oleh IPA PDAM X pada unit Splitter Box untuk air baku yang telah difiltrasi pada unit RWT. Pada penelitian ini dilakukan tahap analisa terhadap pengaruh variasi dosis aluminium sulfat terhadap kekeruhan dan kadar besi air baku pada keadaan sebelum dan sesudah kontak dengan koagulan. Adapun tujuan penelitian ini adalah menentukan dosis optimum penambahan koagulan aluminium sulfat dalam mengurangi tingkat kekeruhan dan sekaligus efeknya terhadap penurunan kadar logam besi dalam air baku khususnya pada IPA PDAM X.

\section{METODOLOGI}

Penelitian dilakukan di Laboratorium Analisa PDAM X dengan menggunakan alat dan bahan kimia meliputi alat jar test, pipet tetes, turbiditymeter, gelas beaker, gelas ukur, tabung reaksi, botol sampel, spektrofotometer visible DR 2010, kuvet $25 \mathrm{~mL}$, air baku sebelum dan sesudah kontak dengan koagulan aluminium sulfat $1 \%$ $(\mathrm{m} / \mathrm{v})$, reagen ferover, dan akuades.

\section{Analisa Kekeruhan}

Cell turbiditymeter dibersihkan dengan akuades dan dibilas dengan sampel yang akan diperiksa kekeruhannya. Sampel air baku sebelum dan sesudah kontak dengan koagulan sebanyak $15 \mathrm{~mL}$ dimasukkan ke dalam cell turbiditymeter. Alat dihidupkan dan dibaca nilai kekeruhannya dalam satuan NTU.

\section{Analisa Kadar Logam Besi}

Penentuan nilai kadar besi dilakukan menggunakan metode kolorimetri dengan alat spektrofotometer visible [9]. Alat spektrofotometer visible dihidupkan dan ditentukan kode pemograman untuk analisa besi dengan kode program 265. Blanko (aquades) dimasukkan ke dalam botol sampel sebanyak $25 \mathrm{ml}$ dan dimasukkan ke dalam alat tekan zero akan timbul pada layar 0,000 A. Sampel air baku (air sungai) diambil $25 \mathrm{ml}$ kemudian reagen ferover (powder pillows, $10 \mathrm{ml}$ ) 1 bungkus ditambahkan dan diaduk. Sampel dimasukkan ke botol sampel $25 \mathrm{~mL}$ dan diletakkan pada alat untuk diukur nilai serapannya.

\section{Metode Jar Test}

Koagulan aluminium sulfat $1 \%(\mathrm{~m} / \mathrm{v})$ atau 10000 ppm dibuat dengan melarutkan 1 gr aluminium sulfat padatan dengan $100 \mathrm{~mL}$ akuades. Enam gelas beaker disiapkan dan diisi dengan sampel air baku masing-masing sebanyak $1000 \mathrm{~mL}$ yang telah diukur kekeruhan dan kadar besi sebelumnya. Gelas beaker disusun pada alat jar test sedemikian rupa dan agitator diturunkan. Kecepatan putaran agitator diatur pada $200 \mathrm{rpm}$ lalu ditambahkan koagulan dengan variasi konsentrasi akhir koagulan masing-masing 10, 12, 15, 20, 25 dan 30 ppm dan dibiarkan selama 1 menit. Kecepatan pengadukan diturunkan menjadi $45 \mathrm{rpm}$ dan dibiarkan selama 17-20 menit. Gelas beaker pertama diangkat dan diberi jeda waktu 30 detik dan diturunkan kecepatan pengadukan menjadi 0 rpm. Sampel didiamkan selama 15 menit untuk selanjutnya diuji kekeruhan dan kadar besinya.

\section{Analisa Data}

Besarnya nilai penurunan kekeruhan dan penurunan kadar besi pada sampel air baku ditentukan dengan selisih antara nilai pada keadaan awal dengan nilai pada keadaan akhir pengukuran. Selanjutnya efisiensi dosis koagulan $(\% \mathrm{E})$ ditentukan dengan persamaan:

$\% E=\frac{A}{B} \times 100 \%$

dengan A merupakan selisih antara nilai pada keadaan awal dengan nilai pada keadaan akhir pengukuran dan B merupakan nilai keadaan awal.

\section{HASIL DAN PEMBAHASAN}

Metode jar test merupakan suatu proses pengujian dosis optimum koagulan yang digunakan dalam proses pengolahan air minum. Proses pengujian yang dilakukan dengan tepat akan sangat berguna untuk membantu teknisi instalasi pengolahan air dalam mengoptimalkan kadar koagulan, proses koagulasi, flokulasi dan penjernihan air baku [10]. Setelah dilakukan jar test maka diperoleh data nilai kekeruhan dan kadar besi sebelum dan sesudah proses koagulasi pada Tabel 1.

Nilai kekeruhan pada sampel air baku setelah penambahan koagulan menunjukkan bahwa semakin tinggi dosis koagulan maka nilai kekeruhan pada sampel menjadi berkurang. Hal ini menyatakan bahwa koagulan aluminium sulfat efektif dalam menurunkan nilai kekeruhan pada sampel air baku sehingga air baku yang nantinya menjadi air bersih layak untuk digunakan. Hasil 
ini juga sejalan dengan penelitian menggunakan koagulan PAC pada IPA PDAM Sidoarjo dengan metode koagulasi - flokulasi - xsedimentasi dimana pada penggunaan dosis koagulan yang semakin tinggi menunjukkan nilai kekeruhan yang semakin rendah [11]. Besar penurunan nilai kekeruhan air baku terhadap variasi dosis koagulan aluminium sulfat dapat ditunjukkan pada Gambar 1. Efisiensi penurunan nilai kekeruhan mencapai 92,67\% menggunakan dosis koagulan $30 \mathrm{ppm}$. Nilai efisiensi dalam penelitian ini termasuk cukup tinggi jika dibandingkan dengan penelitian lainnya yang menunjukkan hasil bahwa dengan dosis optimum $35 \mathrm{ppm}$ aluminium sulfat mampu memberikan efisiensi penurunan kekeruhan sebesar $66,1 \%$ [2]. Penelitian lainnya menunjukkan hasil bahwa dengan campuran koagulan antara aluminium sulfat dan PAC dapat menurunkan kekeruhan pada pengolahan air sungai Tello dengan efisiensi sebesar 82,67\% dengan konsentrasi optimum campuran koagulan sebanyak $25 \%$ [12].

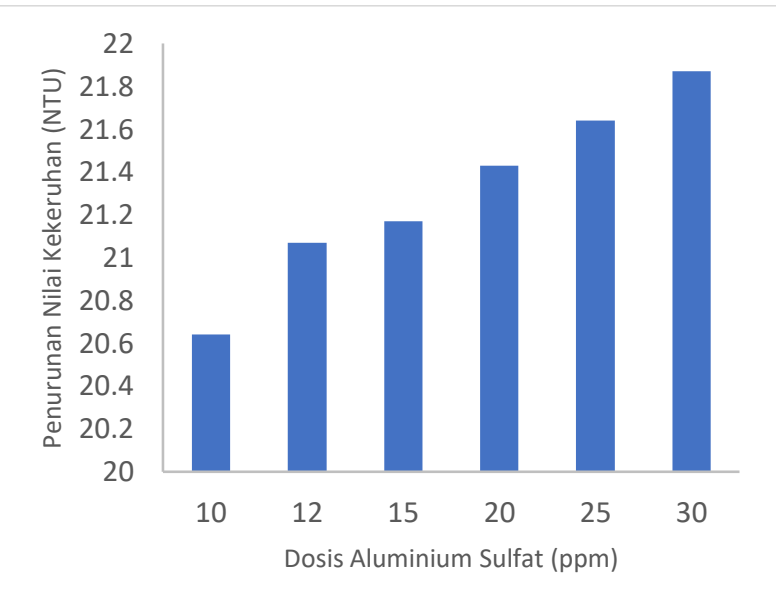

Gambar 1. Profil Penurunan Nilai Kekeruhan terhadap Peningkatan Dosis Koagulan

Selanjutnya berlaku hasil yang sama pada penentuan kadar besi pada sampel air baku dimana semakin tinggi kadar koagulan aluminium sulfat maka semakin turun kadar besi pada sampel air baku. Besar penurunan kadar besi air baku terhadap variasi dosis koagulan aluminium sulfat dapat ditunjukkan pada Gambar 2. Kadar besi turun mencapai $0,74 \mathrm{mg} / \mathrm{L}$ menggunakan dosis koagulan aluminium sulfat $30 \mathrm{ppm}$ dengan tingkat efisiensi sebesar 96,10\%. Hasil ini juga didukung dengan penelitian menggunakan koagulan aluminium sulfat dengan dosis $600 \mathrm{mg} / \mathrm{L}$ dapat menurunkan kadar besi pada larutan uji yang mengandung kadar besi dengan efisiensi mencapai 99,99\% [5].

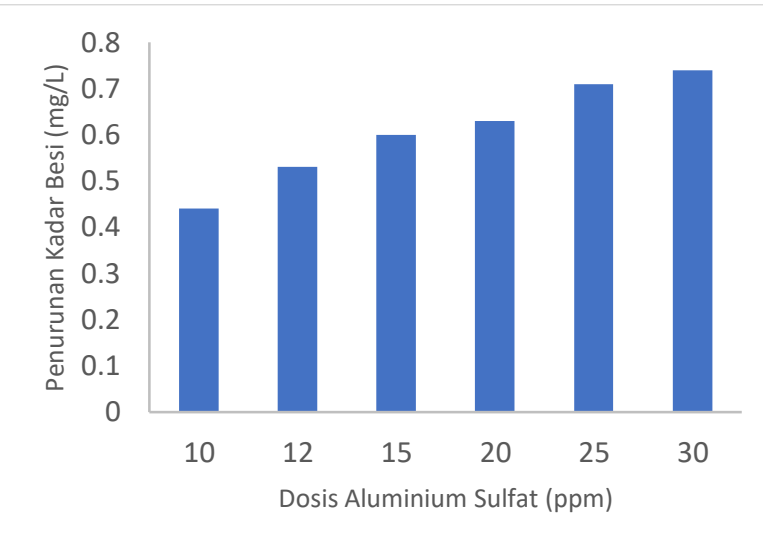

Gambar 2. Profil Penurunan Kadar Besi terhadap Peningkatan Dosis Koagulan

Penelitian lainnya juga menunjukkan bahwa penggunaan aluminium sulfat dengan kadar $75 \%$ dapat menurunkan kadar besi dalam ground water dengan efisiensi sebesar $98,4 \%$ [4]. Lebih lanjut penggunaan aluminium sulfat dengan dosis $5 \mathrm{mg} / \mathrm{L}$ memiliki efisiensi penurunan kadar besi sebanyak $58 \%$ pada air minum dalam kemasan (drinking water). Penggunaan koagulan lainnya seperti biological active carbon (BAC) dengan dosis $5 \mathrm{mg} / \mathrm{L}$ mampu menurunkan kadar besi sebanyak $74 \%$ pada air minum dalam kemasan (drinking water) [13]. Penurunan kadar besi di dalam air disebabkan adanya koagulan aluminium sulfat mengikat partikel-partikel didalam air sehingga logam-logam yang terkandung didalam air seperti kadar besi akan terikut. Semakin banyak dosis koagulan aluminium sulfat yang ditambahkan maka semakin kecil kadar besi didalam air.

Tabel 1. Hasil Analisa Kekeruhan dan Kadar Besi terhadap Variasi Dosis Koagulan

\begin{tabular}{cccccccc}
\hline \multirow{2}{*}{$\begin{array}{l}\text { Volume Air } \\
\text { Baku }(\mathbf{m L})\end{array}$} & \multirow{2}{*}{$\begin{array}{c}\text { Dosis Koagulan } \\
(\mathbf{p p m})\end{array}$} & \multicolumn{3}{c}{ Kekeruhan (NTU) } & \multicolumn{3}{c}{ Kadar Fe (mg/L) } \\
\cline { 3 - 8 } & & Awal & Akhir & Efisiensi (\%) & Awal & Akhir & Efisiensi (\%) \\
\hline 1000 & 10 & 23,6 & 2,96 & 87,46 & 0,77 & 0,33 & 57,14 \\
1000 & 12 & 23,6 & 2,53 & 89,28 & 0,77 & 0,24 & 68,83 \\
1000 & 15 & 23,6 & 2,43 & 89,70 & 0,77 & 0,17 & 77,92 \\
1000 & 20 & 23,6 & 2,17 & 90,81 & 0,77 & 0,14 & 81,82 \\
1000 & 25 & 23,6 & 1,96 & 91,69 & 0,77 & 0,06 & 92,21 \\
1000 & 30 & 23,6 & 1,73 & 92,67 & 0,77 & 0,03 & 96,10 \\
\hline
\end{tabular}




\section{KESIMPULAN}

Berdasarkan penelitian yang telah dilakukan di IPA PDAM X maka dapat disimpulkan bahwa dengan penggunaan dosis koagulan yang semakin tinggi maka nilai kekeruhan dan kadar besi dari sampel air baku semakin turun. Ini menunjukkan bahwa koagulan aluminium sulfat efektif dalam proses penjernihan air baku sehingga nantinya diperoleh air bersih yang layak digunakan. Dosis koagulan aluminium sulfat sebesar 30 ppm dapat memberikan efisiensi penurunan nilai kekeruhan mencapai 92,67\% dan penurunan kadar besi pada air baku sebesar $96,10 \%$.

\section{DAFTAR PUSTAKA}

[1] K. E. S. Manik, Pengelolaan Lingkungan Hidup. Jakarta: Djambatan, 2003.

[2] R. Mayasari and M. Hastarina, "Optimalisasi Dosis Koagulan Aluminium Sulfat dan Poli Aluminium Klorida (PAC) (Studi Kasus PDAM Tirta Musi Palembang)," Integrasi, vol. 3, no. 2, pp. 28-36, 2018.

[3] M. E. El-dardeer, A. A. H. Mohamed, A. A. R. Mohamed, and H. M. S. Abdelazim, "Effect of Alum Coagulation on iron Removal in Aerated Groundwater Using Rapid Sand Filters," J. Eng. Sci. Assiut Univ. Fac. Eng., vol. 44, no. 6, pp. 690-702, 2016.

[4] P. Sarker, S. Islam, and M. M. Kabir, "Removal of iron and turbidity from ground water by natural and chemical coagulants," Int. Res. J. Environ. Sci., vol. 8, no. 1, pp. 36-41, 2019.

[5] M. F. Pang, P. Kumar, T. T. Teng, A. K. M. Omar, and K. L. Wasewar, "Removal of lead, zinc and iron by coagulation - flocculation," $J$. Taiwan Inst. Chem. Eng., vol. 42, no. 5, pp. 809815, 2011, doi: 10.1016/j.jtice.2011.01.009.

[6] M. D. Pusfitasari, R. R. Yogaswara, D. M. Jiwantara, and I. R. Anggara, "Penurunan Kandungan Besi (Fe) dalam Air Tanah dengan Metode Elektrokoagulasi," J. Tek. Kim., vol. 12, no. 2, pp. 59-63, 2018.

[7] I. Nurhayati and S. Vigiani, "Penurunan Kadar Besi (Fe), Kromium (Cr), COD dan BOD Limbah Cair Laboratorium dengan Pengenceran, Koagulasi dan Adsorbsi," Ecotrophic, vol. 14, no. 1, pp. 74-87, 2020.

[8] F. Reno, "Penggunaan Aluminium Sulfat Untuk Menurunkan Kekeruhan Dan Warna Pada Limbah Cair Stockpile Batubara Dengan Metode Koagulasi Dan Flokulasi," J. Redoks, vol. 2, no. 1, pp. 42-47, 2017.

[9] K. Khaira, "Penentuan Kadar Besi (Fe) Air Sumur dan Air PDAM Dengan Metode
Spektrofotometri," J. Sainstek, vol. V, no. 1, pp. 17-23, 2013.

[10] Margaretha, R. Mayasari, Syaiful, and Subroto, "Pengaruh Kualitas Air Baku Terhadap Dosis dan Biaya Koagulan Aluminium Sulfat dan Poly Aluminium Chloride," J. Tek. Kim., vol. 18, no. 4, pp. 21-30, 2012.

[11] A. Chamdan and A. Purnomo, "Kajian Kinerja Teknis Proses dan Operasi Unit KoagulasiFlokulasi-Sedimentasi pada Instalasi Pengolahan Air (IPA) Kedunguling PDAM Sidoarjo," J. Tek. Pomits, vol. 2, no. 2, pp. 118-123, 2013.

[12] S. E. Widiyanti, P. Pabbenteng, E. W. Saputra, and A. N. Islamiati, "Optimasi Proses Koagulasi Menggunakan Campuran Koagulan Aluminium Sulfat Dan PAC (Poly Aluminium Chloride) Pada Pengolahan Air Sungai Tello," in Seminar Nasional “Tellu Cappa,” 2017, vol. September, pp. 681-684, doi: 10.20527/k.v8i1.6515.

[13] B. K. Pramanik, S. K. Pramanik, and F. Suja, "Removal of arsenic and iron removal from drinking water using coagulation and biological treatment," J. Water Health, vol. 14, no. 1, pp. 90-96, 2016, doi: 10.2166/wh.2015.159. 